\title{
Effect of thermal conditions on the incubation period of wheat leaf rust
}

\section{Wpływ warunków termicznych na okres inkubacji rdzy brunatnej pszenicy}

\author{
Andrzej Wójtowicz ${ }^{1 *}$, Marek Wójtowicz ${ }^{2}$, Maria Pasternak ${ }^{1}$, Katarzyna Pieczul ${ }^{1}$, \\ Ilona Świerczyńska ${ }^{1}, K^{1}$ atarzyna Sadowska ${ }^{1}$
}

\section{Summary}

The aim of the study was to mathematically compile the effect of temperature on the length of the wheat brown rust incubation period. Experiments aimed at achieving this goal were carried out in quazi-natural conditions in the years 2013-2015. The experiments consisted in carrying out wheat inoculation with Puccinia recondita f. sp. tritici spores and determining the date of occurrence of the first brown rust disease symptoms. The obtained results were used to develop the model determining the length of the incubation period based on average daily air temperatures.

Key words: Puccinia recondita, wheat, incubation period, model

\section{Streszczenie}

Celem pracy było matematyczne opracowanie wpływu temperatury na długość okresu inkubacji rdzy brunatnej pszenicy. Doświadczenia ukierunkowane na osiągnięcie założonego celu przeprowadzono w warunkach quazi-naturalnych w latach 2013-2015. Eksperymenty polegały na przeprowadzeniu inokulacji pszenicy zarodnikami Puccinia recondita f. sp. tritici i określeniu terminu wystąpienia pierwszych objawów chorobowych rdzy brunatnej. Uzyskane wyniki wykorzystano do opracowania modelu wyznaczającego długość okresu inkubacji na podstawie średnich dobowych temperatur powietrza.

Słowa kluczowe: Puccinia recondita, pszenica, okres inkubacji, model

\author{
Instytut Ochrony Roślin - Państwowy Instytut Badawczy \\ Władysława Węgorka 20, 60-318 Poznań \\ 2Instytut Hodowli i Aklimatyzacji Roślin - Państwowy Instytut Badawczy \\ Oddział w Poznaniu \\ Strzeszyńska 36, 60-479 Poznań \\ corresponding author: a.wojtowicz@iorpib.poznan.pl \\ ORCID: 0000-0003-1455-1527
}




\section{Wstęp / Introduction}

Rdza brunatna pszenicy występuje we wszystkich rejonach uprawy pszenicy jarej i ozimej (Aoun i wsp. 2016). Sprawca choroby grzyb Puccinia recondita f. sp. tritici zaliczany jest do patogenów wywołujących epifitozy policykliczne. Tempo rozwoju takich epifitoz zależy w dużym stopniu od długości okresu inkubacji, definiowanego jako okres od nawiązania kontaktu pasożytniczego patogena z rośliną do wystąpienia objawów chorobowych (Copes i Thomson 2008; Leclerc i wsp. 2014). Długość okresu inkubacji determinowana jest przede wszystkim warunkami termicznymi (Xu i Robinson 2000). Znaczenie innych czynników meteorologicznych, takich jak wiatr, deszcz czy wilgotność powietrza $\mathrm{w}$ okresie od wniknięcia patogena do rośliny do momentu wystąpienia objawów chorobowych nie odgrywa istotnej roli w modyfikacji nasilenia objawów choroby. Optymalne warunki dla inkubacji rdzy brunatnej pszenicy zapewnia temperatura zbliżona do $20-25^{\circ} \mathrm{C}$, a niższe temperatury skutkują wydłużeniem okresu inkubacji (Wójtowicz 2012). Z uwagi na kluczowe znaczenie okresu inkubacji w rozwoju epifitoz, określenie roli warunków środowiskowych w modyfikacji tego etapu procesu chorobowego stanowiło podstawowy cel licznych prac naukowych (Shaner i Finney 1980; van der Gaag i Jacobs 1997; Lovell i wsp. 2004; Xu i wsp. 2005; Madden i wsp. 2007; Pariaud i wsp. 2013; Riaz i wsp. 2016). W badaniach nad chorobami roślin dużo uwagi poświęcono również na opracowanie w formie równań matematycznych zależności występujących pomiędzy warunkami środowiska i okresem inkubacji (Karolewski i wsp. 2002; Kolnaar 2006; Fisher i wsp. 2008). W odniesieniu do rdzy występujących na zbożach badania $\mathrm{w}$ tym zakresie były prowadzone między innymi przez: Pfendera (2001), Nopsę i Pfendera (2014), Wójtowicza i wsp. (2017) oraz Alfonsi i wsp. (2019). Wyniki badań ukierunkowanych na liczbowe wyrażenie związku między parametrami meteorologicznymi a rozwojem patogenów, znajdują coraz częściej zastosowanie w realizacji przedsięwzięć ukierunkowanych na opracowanie narzędzi wspomagających monitorowanie epifitoz (Webb i wsp. 2000; van Maanen i Xu 2003; Huang i wsp. 2007) i szacowanie strat w plonach generowanych przez mikroorganizmy chorobotwórcze (Savary i wsp. 2006; Willocquet i wsp. 2008).

Celem pracy było wyrażenie w formie równań matematycznych wpływu temperatury na inkubację sprawcy rdzy brunatnej pszenicy.

\section{Materiały i metody / Materials and methods}

Obiektem badań realizowanych w latach 2013-2015 była pszenica ozima odmiany Turnia. W dziewięciostopniowej skali, według której 1 - oznacza wysoką podatność, a 9 - pełną odporność na porażenie przez $P$. recondita f. sp. tritici, odmianę Turnia określa wartość 6,0 (Gacek 2013) i zaliczana jest ona do odmian podatnych.

Eksperymenty ukierunkowane na opracowanie modelu polegały na przeprowadzeniu inokulacji pszenicy i określeniu terminu wystąpienia objawów chorobowych rdzy brunatnej. Liczba doświadczeń realizowanych w latach 2013, 2014 i 2015 wynosiła odpowiednio: 20, 26 i 22. Wszystkie eksperymenty przeprowadzono w 3 powtórzeniach. Za każdym razem do 3 doniczek o średnicy $10 \mathrm{~cm}$ wysiewano po 60 ziarniaków pszenicy. Po osiągnięciu przez rośliny fazy drugiego liścia (BBCH 12) poddawano je inokulacji. Inokulum stanowiła zawiesina urediniospor pozyskiwanych z pszenicy uprawianej w Winnej Górze w latach 2013-2015. Koncentracja urediniospor w zastosowanym inokulum wynosiła $3,1 \times 10^{5}$ zarodników $/ \mathrm{ml}$. Po inokulacji rośliny przetrzymywano przez 24 godziny w temperaturze $15^{\circ} \mathrm{C}$ w workach foliowych gwarantujących zwilżenie liści optymalne dla efektywnej infekcji. Następnie przenoszono rośliny do warunków polowych i poddawano codziennej obserwacji kontynuowanej do dnia wystąpienia pierwszych urediniów na jednej z 60 roślin w każdej z 3 doniczek. Wyniki doświadczeń wykorzystano do opracowania modelu inkubacji rdzy brunatnej pszenicy. Do tego celu wykorzystano okresy inkubacji obliczone na podstawie obserwacji roślin w 3 doniczkach. Niezbędne do opracowania modelu dane meteorologiczne pobrano ze strony internetowej dostępnej pod adresem https://weather.gladstonefamily.net/site/ EPPO. Wszystkie przedstawione $\mathrm{w}$ niniejszej pracy dane charakteryzujące warunki termiczne, w których realizowano doświadczenia są średnimi temperaturami dobowymi. Do opracowania modelu zastosowano funkcję wykładniczą w następującej postaci:

$$
\mathrm{I}_{[\mathrm{d}]}=\mathrm{a}+\exp (\mathrm{b}+\mathrm{c} \times \mathrm{T})[1]
$$

gdzie: $\mathrm{I}_{[\mathrm{d}]}-$ okres inkubacji P. recondita f. sp. tritici [dni], $\mathrm{T}$ - temperatura $\left[{ }^{\circ} \mathrm{C}\right], \mathrm{a}, \mathrm{b}, \mathrm{c}-$ współczynniki równania.

Przy wyborze funkcji do opisania zależności między analizowanymi parametrami wzorowano się na publikacji Behlau i wsp. (2017), którzy zastosowali takie równanie do oceny wpływu miedzi na powierzchnię pod krzywą rozwoju raka cytrusów oraz na liczbę owoców pomarańczy porażonych przez Xanthomonas citri subsp. citri. Wartości współczynników i statystyczne parametry opracowanego modelu opisującego wpływ temperatury na długość okresu inkubacji rdzy brunatnej pszenicy przedstawiono w tabeli 4. Dopasowanie funkcji do danych empirycznych oraz ocenę tego dopasowania, oszacowaną na podstawie wartości współczynnika determinacji $\mathrm{R}^{2}$, jak również ocenę istotności współczynników uzyskanego równania przeprowadzono z zastosowaniem modułu „estymacja nieliniowa" dostępnego w pakiecie STATISTICA 12. 


\section{Wyniki i dyskusja / Results and discussion}

Czas inkubacji był zależny od temperatury i mieścił się w zakresie 5-19 dni (tab. 1). Wystąpienie pierwszych urediniów na roślinach inokulowanych w tym samym terminie w każdej z trzech doniczek obserwowano każdorazowo tego samego dnia. W przeprowadzonych doświadczeniach nie odnotowano dużego zróżnicowania wyników pomiędzy latami. Średnia długość okresu inkubacji w 2013 r. wynosiła 9 dni w temperaturze $15,9^{\circ} \mathrm{C}$, w 2014 r. -9 dni w temperaturze $15,5^{\circ} \mathrm{C}$, a w $2015 \mathrm{r}$. $-10 \mathrm{dni}$ w temperaturze $14,2^{\circ} \mathrm{C}$. Większe różnice stwierdzono natomiast przy porównaniu długości okresu inkubacji w analizowanych miesiącach.

W 2013 r. okres inkubacji mieścił się w zakresie 5-14 dni (tab. 1). W kwietniu okres inkubacji wynosił od 8 do 14 dni w temperaturze $7,4-13,9^{\circ} \mathrm{C}$. W maju objawy chorobowe rdzy wystąpiły po 7 do 10 dniach po inokulacji w zakresie temperatury $13,7-16,7^{\circ} \mathrm{C}$. W czerwcu i lipcu okres inkubacji przyjmował odpowiednio wartości z zakresu 6-8 oraz 6-7 dni w temperaturze $17,5-20,6^{\circ} \mathrm{C}$ oraz $18,1-$ $23,9^{\circ} \mathrm{C}$. W sierpniu objawy rdzy wystąpiły po 5 dniach w temperaturze $24,3^{\circ} \mathrm{C}$, a we wrześniu po 11 do 13 dniach w temperaturze $8,5-13,0^{\circ} \mathrm{C}$. W październiku w temperaturze $9,9^{\circ} \mathrm{C}$ okres inkubacji wynosił 12 dni.

W 2014 r. okres inkubacji mieścił się w zakresie 6-14 dni (tab. 2). W marcu w temperaturze $7,9-9,2^{\circ} \mathrm{C}$ czas inkubacji wynosił od 10 do 13 dni. W kwietniu objawy chorobowe wystąpiły po 8 do 10 dniach po inokulacji w temperaturze $7,7-14,8^{\circ} \mathrm{C}$, a w maju po 6 do 9 dniach w temperaturze $13,9-21,0^{\circ} \mathrm{C}$. W czerwcu inkubacja trwała 7 do 8 dni, a w lipcu 7 dni w temperaturze odpowiednio $14,9-20,7^{\circ} \mathrm{C}$ oraz $21,3-23,7^{\circ} \mathrm{C}$. W sierpniu objawy rdzy zarejestrowano po 7 dniach po inokulacji przy temperaturze $21,3^{\circ} \mathrm{C}$, a we wrześniu po 8 do 9 dniach $\mathrm{w}$ temperaturze $13,2-13,8^{\circ} \mathrm{C}$. W październiku przy temperaturze $7,7-15,0^{\circ} \mathrm{C}$ objawy rdzy brunatnej odnotowano po 8-16 dniach.

W 2015 r. wystąpienie objawów rdzy brunatnej odnotowano po 7-18 dniach po inokulacji (tab. 3). W marcu długość okresu inkubacji wynosiła 15-18 dni, a w kwietniu 9-11 dni przy temperaturze odpowiednio $5,8-6,3^{\circ} \mathrm{C}$ oraz $9,9-12,5^{\circ} \mathrm{C}$. W maju objawy rdzy odnotowano po 9 dniach przy temperaturze $13,4-15,8^{\circ} \mathrm{C}$, a w czerwcu po $7-11$ dniach przy temperaturze $14,7-17,6^{\circ} \mathrm{C}$. W lipcu przy temperaturze odpowiednio $17,6-22,5^{\circ} \mathrm{C}$ okres inkubacji wynosił $7-8 \mathrm{dni}$,

Tabela 1. Wyniki doświadczeń realizowanych w 2013 roku nad wpływem temperatury na okres inkubacji rdzy brunatnej pszenicy Table 1. Results of the experiments carried out in 2013 on the effect of temperature on the incubation period of wheat leaf rust

\begin{tabular}{|c|c|c|c|}
\hline $\begin{array}{l}\text { Data inokulacji } 180 \text { roślin } \\
\text { Date of inoculation } 180 \text { plants }\end{array}$ & $\begin{array}{c}\text { Data wystąpienia pierwszych } \\
\text { objawów chorobowych rdzy } \\
\text { brunatnej } \\
\text { Date of leaf rust first symptoms } \\
\text { appearance }\end{array}$ & $\begin{array}{c}\text { Okres inkubacji } \\
\text { [dni] } \\
\text { Incubation period } \\
\text { [days] }\end{array}$ & $\begin{array}{c}\text { Średnia temperatura dobowa } \\
\text { Average daily temperature } \\
\qquad\left[{ }^{\circ} \mathrm{C}\right]\end{array}$ \\
\hline 04.04 .2013 & 18.04 .2013 & 14 & 7,4 \\
\hline 18.04.2013 & 26.04 .2013 & 8 & 13,9 \\
\hline 25.04 .2013 & 04.05 .2013 & 9 & 12,2 \\
\hline 09.05 .2013 & 17.05 .2013 & 8 & 16,3 \\
\hline 16.05 .2013 & 23.05 .2013 & 7 & 16,7 \\
\hline 23.05 .2013 & 02.06 .2013 & 10 & 13,7 \\
\hline 27.05 .2013 & 04.06 .2013 & 8 & 15,2 \\
\hline 06.06 .2013 & 14.06 .2013 & 8 & 18,3 \\
\hline 13.06 .2013 & 19.06.2013 & 6 & 20,6 \\
\hline 20.06 .2013 & 28.06 .2013 & 8 & 18,5 \\
\hline 27.06 .2013 & 04.07 .2013 & 7 & 17,5 \\
\hline 04.07 .2013 & 10.07 .2013 & 6 & 20,6 \\
\hline 11.07 .2013 & 18.07.2013 & 7 & 18,1 \\
\hline 18.07.2013 & 24.07 .2013 & 6 & 21,1 \\
\hline 25.07 .2013 & 31.07 .2013 & 6 & 23,9 \\
\hline 01.08 .2013 & 06.08 .2013 & 5 & 24,3 \\
\hline 12.09 .2013 & 23.09 .2013 & 11 & 13,0 \\
\hline 18.09 .2013 & 30.09 .2013 & 12 & 10,6 \\
\hline 26.09 .2013 & 09.10 .2013 & 13 & 8,5 \\
\hline 02.10 .2013 & 14.10 .2013 & 12 & 9,9 \\
\hline
\end{tabular}


Tabela 2. Wyniki doświadczeń realizowanych w 2014 roku nad wpływem temperatury na okres inkubacji rdzy brunatnej pszenicy Table 2. Results of the experiments carried out in 2014 on the effect of temperature on the incubation period of wheat leaf rust

\begin{tabular}{|c|c|c|c|}
\hline $\begin{array}{l}\text { Data inokulacji } 180 \text { roślin } \\
\text { Date of inoculation } 180 \text { plants }\end{array}$ & $\begin{array}{c}\text { Data wystąpienia pierwszych } \\
\text { objawów chorobowych rdzy } \\
\text { brunatnej } \\
\text { Date of leaf rust first symptoms } \\
\text { appearance }\end{array}$ & $\begin{array}{l}\text { Okres inkubacji } \\
\text { [dni] } \\
\text { Incubation period } \\
\text { [days }]\end{array}$ & $\begin{array}{c}\text { Średnia temperatura dobowa } \\
\text { Average daily temperature } \\
{\left[{ }^{\circ} \mathrm{C}\right]}\end{array}$ \\
\hline 18.03 .2014 & 31.03 .2014 & 13 & 8,6 \\
\hline 25.03 .2014 & 04.04 .2014 & 10 & 7,9 \\
\hline 31.03 .2014 & 11.04 .2014 & 11 & 9,2 \\
\hline 09.04 .2014 & 18.04 .2014 & 9 & 7,7 \\
\hline 16.04 .2014 & 24.04 .2014 & 8 & 12,4 \\
\hline 22.04 .2014 & 30.04 .2014 & 8 & 14,8 \\
\hline 28.04 .2014 & 08.05 .2014 & 10 & 11,2 \\
\hline 15.05 .2014 & 23.05 .2014 & 8 & 17,1 \\
\hline 21.05 .2014 & 27.05 .2014 & 6 & 21,0 \\
\hline 28.05 .2014 & 06.06 .2014 & 9 & 13,9 \\
\hline 04.06 .2014 & 11.06 .2014 & 7 & 20,6 \\
\hline 11.06 .2014 & 19.06 .2014 & 8 & 16,7 \\
\hline 16.06 .2014 & 24.06 .2014 & 8 & 14,9 \\
\hline 23.06 .2014 & 30.06 .2014 & 7 & 16,3 \\
\hline 30.06 .2014 & 07.07 .2014 & 7 & 20,7 \\
\hline 07.07 .2014 & 14.07 .2014 & 7 & 21,3 \\
\hline 14.07 .2014 & 21.07 .2014 & 7 & 23,7 \\
\hline 21.07 .2014 & 28.07 .2014 & 7 & 22,5 \\
\hline 28.07 .2014 & 04.08 .2014 & 7 & 23,0 \\
\hline 04.08 .2014 & 11.08 .2014 & 7 & 21,3 \\
\hline 17.09 .2014 & 26.09 .2014 & 9 & 13,8 \\
\hline 25.09 .2014 & 03.10 .2014 & 8 & 13,2 \\
\hline 30.09 .2014 & 09.10 .2014 & 9 & 13,4 \\
\hline 06.10 .2014 & 14.10 .2014 & 8 & 15,0 \\
\hline 13.10 .2014 & 23.10 .2014 & 10 & 12,3 \\
\hline 20.10 .2014 & 05.11 .2014 & 16 & 7,7 \\
\hline
\end{tabular}

- a w sierpniu przy temperaturze $25,8^{\circ} \mathrm{C}-7$ dni. We wrześniu objawy wystąpiły 9-10 dni po inokulacji w zakresie temperatury $10,7-12,6^{\circ} \mathrm{C}$, a w październiku w temperaturze wynoszącej $8,1^{\circ} \mathrm{C}$ po 13 dniach.

Wyniki przeprowadzonych doświadczeń potwierdziły silny związek między temperaturą i długością okresu inkubacji (tab. 1, 2, 3). Najkrótszy okres inkubacji wynoszący 5 dni zarejestrowano przy średniej temperaturze $24,3{ }^{\circ} \mathrm{C}$. Wydłużenie okresu inkubacji o 1-2 dni w porównaniu $\mathrm{z}$ okresem najkrótszym odnotowano $\mathrm{W}$ temperaturze $20,6-21,4^{\circ} \mathrm{C}$. W temperaturze około $13^{\circ} \mathrm{C}$ zarejestrowano wydłużenie okresu inkubacji o $4 \mathrm{dni}$, a w temperaturze 7-8 ${ }^{\circ} \mathrm{C}$ okres inkubacji zwiększył się o 8-9 dni. Najdłuższy okres inkubacji wynoszący 18 dni (13 dni dłuższy od najkrótszego) odnotowano $\mathrm{w}$ temperaturze około $6^{\circ} \mathrm{C}$.
Wysoka wartość współczynnika determinacji $\mathrm{R}^{2}$ charakteryzującego model inkubacji rdzy brunatnej pszenicy, opracowanego na podstawie wyników eksperymentów realizowanych w latach 2013-2015 wskazuje na dobre dopasowanie opracowanego modelu do danych empirycznych i potwierdza poprawność wyboru funkcji wykładniczej do matematycznego opracowania analizowanych zależności. Funkcja wykładnicza obok monomolekularnej, logistycznej i Gompertza znajduje powszechnie zastosowanie w badaniach ukierunkowanych na wyjaśnienie roli środowiska w rozwoju patogenów roślin (Jeger 2004; Nutter 2007). Najważniejszą zaletą wymienionych funkcji jest możliwość dobrego dopasowania modelu do danych empirycznych przy zastosowaniu niewielkiej liczby zmiennych (Xu 2006). Przedstawiony w niniejszej pracy matematyczny opis wpły- 
Tabela 3. Wyniki doświadczeń realizowanych w 2015 roku nad wpływem temperatury na okres inkubacji rdzy brunatnej pszenicy Table 3. Results of the experiments carried out in 2015 on the effect of temperature on the incubation period of wheat leaf rust

\begin{tabular}{|c|c|c|c|}
\hline $\begin{array}{l}\text { Data inokulacji } 180 \text { roślin } \\
\text { Date of inoculation } 180 \text { plants }\end{array}$ & $\begin{array}{c}\text { Data wystąpienia pierwszych } \\
\text { objawów chorobowych rdzy } \\
\text { brunatnej } \\
\text { Date of leaf rust first symptoms } \\
\text { appearance }\end{array}$ & $\begin{array}{l}\text { Okres inkubacji } \\
\text { [dni] } \\
\text { Incubation period } \\
\text { [days }]\end{array}$ & $\begin{array}{c}\text { Średnia temperatura dobowa } \\
\text { Average daily temperature } \\
\qquad\left[{ }^{\circ} \mathrm{C}\right]\end{array}$ \\
\hline 23.03 .2015 & 10.04 .2015 & 18 & 5,8 \\
\hline 30.03 .2015 & 14.04 .2015 & 15 & 6,3 \\
\hline 08.04 .2015 & 17.04 .2015 & 9 & 9,9 \\
\hline 16.04 .2015 & 27.04 .2015 & 11 & 11,3 \\
\hline 27.04 .2015 & 07.05 .2015 & 10 & 12,5 \\
\hline 06.05 .2015 & 15.05 .2015 & 9 & 13,7 \\
\hline 11.05 .2015 & 20.05 .2015 & 9 & 13,4 \\
\hline 18.05 .2015 & 27.05 .2015 & 9 & 14,0 \\
\hline 25.05 .2015 & 03.06 .2015 & 9 & 15,8 \\
\hline 02.06 .2015 & 09.06 .2015 & 7 & 17,6 \\
\hline 11.06 .2015 & 19.06 .2015 & 8 & 16,4 \\
\hline 18.06 .2015 & 29.06 .2015 & 11 & 14,7 \\
\hline 24.06 .2015 & 02.07 .2015 & 8 & 17,3 \\
\hline 02.07 .2015 & 09.07 .2015 & 7 & 22,5 \\
\hline 09.07 .2015 & 17.07 .2015 & 8 & 17,6 \\
\hline 16.07 .2015 & 23.07 .2015 & 7 & 21,6 \\
\hline 22.07 .2015 & 30.07 .2015 & 8 & 19,0 \\
\hline 28.07 .2015 & 04.08 .2015 & 7 & 19,9 \\
\hline 03.08 .2015 & 10.08 .2015 & 7 & 25,8 \\
\hline 21.09 .2015 & 30.09 .2015 & 9 & 12,6 \\
\hline 28.09 .2015 & 08.10 .2015 & 10 & 10,7 \\
\hline 01.10 .2015 & 14.10 .2015 & 13 & 8,1 \\
\hline
\end{tabular}

Tabela 4. Parametry równania $\mathrm{I}_{[\mathrm{d}]}=\mathrm{a}+\exp (\mathrm{b}+\mathrm{c} \times \mathrm{T})$ [1], opisującego wpływ temperatury $(\mathrm{T})$ na długość okresu inkubacji (I) rdzy brunatnej pszenicy

Tabela 4. Parameters of equation $\mathrm{I}_{[\mathrm{d}]}=\mathrm{a}+\exp (\mathrm{b}+\mathrm{c} \times \mathrm{T})$ [1], expressing the influence of temperature (T) on the incubation period (I) of wheat leaf rust

\begin{tabular}{c|c|c|c|c|c|c|c}
\hline \multirow{2}{*}{$\begin{array}{c}\text { Nr modelu } \\
\text { No. of } \\
\text { a model }\end{array}$} & \multicolumn{3}{|c|}{$\begin{array}{c}\text { Wartości współczynników } \\
\text { Values of coefficients }\end{array}$} & \multicolumn{4}{c}{$\begin{array}{c}\text { Parametry statystyczne } \\
\text { Values of statistical parameters }\end{array}$} \\
\cline { 2 - 9 } & \multicolumn{2}{|c|}{$\mathrm{c}$} & $\mathrm{c}$ & $\mathrm{a}$ & $\mathrm{b}$ & $\mathrm{c}$ & $\mathrm{R}^{2}$ \\
\hline 1 & 5,992963 & 3,20964 & 0,15866 & 0,00000 & 0,00000 & 0,00000 & 0,81 \\
\hline
\end{tabular}

wu temperatury na okres inkubacji koresponduje z podejściem prezentowanym przez Kolnaara (2006), który do tego celu również zastosował funkcję wykładniczą. Z kolei Webb i Nutter (1997) do matematycznego opisu okresu inkubacji rdzy lucerny zastosowali funkcje Gompertza, Fisher i wsp. (2008) funkcję wielomianową drugiego stopnia do opisu okresu inkubacji Puccinia jaceae var. solstitialis, a Räder i wsp. (2007) w badaniach nad okresem inkubacji rdzy żyta wykorzystał zmodyfikowaną wersję funkcji beta.
Wyniki przeprowadzonych doświadczeń stanowią potwierdzenie wcześniejszych badań ukierunkowanych na opracowanie wpływu warunków termicznych na długość okresu inkubacji rdzy brunatnej pszenicy. Ścisły związek pomiędzy temperaturą a terminem wystąpienia objawów chorobowych rdzy brunatnej pszenicy wykazali między innymi Pretorius i wsp. (1994), którzy w doświadczeniach nad efektami prac hodowlanych ukierunkowanych na zwiększenie odporności pszenicy na $P$. recondita f. sp. 
tritici odnotowali istotne różnice w długości okresu inkubacji indukowane podwyższeniem temperatury z 15 do $25^{\circ} \mathrm{C}$. $\mathrm{O}$ różnicującym wpływie temperatury na okres inkubacji sprawcy rdzy brunatnej pszenicy donoszą również Drijepondt i Pretorius (1989), którzy w badaniach przeprowadzonych w temperaturze $13-17^{\circ} \mathrm{C}$, z zastosowaniem linii hodowlanej RL6058, stwierdzili opóźnienie terminu wystąpienia objawów chorobowych po inokulacji w fazie grubienia pochwy liściowej i w fazie kłoszenia odpowiednio o trzy i cztery dni w porównaniu do wyników doświadczeń realizowanych w temperaturze $26-30^{\circ} \mathrm{C}$. O wydłużeniu okresu inkubacji rdzy brunatnej pszenicy w następstwie obniżenia temperatury donoszą także Eyal i Peterson (1967), Johnson (1980), Tomerlin i wsp. (1983), Broers i Wallenburg (1989) oraz Kolmer (2009). W eksperymentach przeprowadzonych przez Eversmeyera i wsp. (1980) z zastosowaniem odmiany Thacher, autorzy wykazali ścisły związek pomiędzy temperaturą i terminem wystąpienia objawów chorobowych rdzy brunatnej. W następstwie podniesienia temperatury otoczenia z $10^{\circ} \mathrm{C}$ do $15,6^{\circ} \mathrm{C}$ odnotowali przyspieszenie terminu wystąpienia objawów rdzy o jeden dzień. Dalsze skrócenie okresu inkubacji wynoszące trzy i pięć dni stwierdzili $\mathrm{w}$ efekcie podwyższenia temperatury odpowiednio do $21,1^{\circ} \mathrm{C}$ i $26,7^{\circ} \mathrm{C}$. Zależności pomiędzy temperaturą w zakresie $10-26,7^{\circ} \mathrm{C}$ a długością okresu inkubacji wykazane w badaniach Eversmeyera i wsp. (1980) nie mają charakteru liniowego, a do ich opisania można wykorzystać funkcję wykładniczą, co koresponduje z wynikami przedstawionymi w niniejszej pracy. Zaprezentowane w niniejszej pracy rezultaty doświadczeń ukierunkowanych na opracowanie modelu inkubacji sprawcy rdzy brunatnej pszenicy korespondują również z wynikami eksperymentów realizowanych w warunkach kontrolowanych w roku 2010, kiedy podwyższenie temperatury z $10^{\circ} \mathrm{C}$ do $15,20 \mathrm{i} 25^{\circ} \mathrm{C}$ skutkowało skróceniem okresu inkubacji odpowiednio o 12, 13 i 14 dni (Wójtowicz 2012), a zależność pomiędzy temperaturą i długością okresu inkubacji wyrażono z wykorzysta- niem funkcji wykładniczej. Liczbowe wyrażenie zależności między temperaturą i długością okresu inkubacji jest podstawowym warunkiem opracowania wiarygodnego systemu monitorowania zagrożenia roślin przez patogeny. Dotyczy to w szczególności sytuacji, w których długość okresu inkubacji sprawcy decyduje o frekwencji kolejnych jego generacji (Xu 2006; Windes 2008; Suffert i Thompson 2018). W odniesieniu do rdzy brunatnej długość okresu inkubacji sprawcy implikuje liczbę generacji urediniospor i tym samym znacząco modyfikuje tempo rozprzestrzeniania grzyba. Potwierdzeniem znaczenia okresu inkubacji w kształtowaniu epifitoz jest uwzględnienie tego parametru nie tylko przy opracowaniu systemów wspomagających podejmowanie decyzji w ochronie roślin (Kluge i wsp. 2006; Kleinhenz i wsp. 2007; Racca i wsp. 2007; Räder i wsp. 2007), ale również $\mathrm{w}$ badaniach ukierunkowanych na szacowanie zagrożenia roślin przez patogeny generowanego zmianami klimatu (Ghini i wsp. 2011; Shakya i wsp. 2015; Wójtowicz i wsp. 2017, 2019).

\section{Wnioski / Conclusions}

1. Wysoka wartość współczynnika determinacji $\mathrm{R}^{2}$ charakteryzującego model inkubacji rdzy brunatnej pszenicy, opracowanego na podstawie wyników eksperymentów realizowanych w latach 2013-2015, wskazuje na dobre dopasowanie modelu do danych empirycznych i jednocześnie potwierdza znaczenie warunków termicznych w kształtowaniu długości okresu inkubacji.

2. Rezultaty przeprowadzonych eksperymentów wskazują na możliwości zastosowania opracowanego modelu w badaniach ukierunkowanych na wyjaśnienie roli warunków termicznych we wzajemnym oddziaływaniu rośliny i patogena.

\section{Literatura / References}

Alfonsi W.M.V., Coltri P.P., Zullo Júnior J., Patrício F.R.A., Gonçalves R.R., Shinji K., Alfonsi E.L., Koga-Vicente A. 2019. Geographical distribution of the incubation period of coffee leaf rust in climate change scenarios. Pesquisa Agropecuária Brasileira 54: e00273. DOI: 10.1590/S1678-3921.pab2019.v54.00273

Aoun M., Breiland M., Turner K., Loladze A., Chao S., Xu S., Ammar K., Anderson J.A., Kolmer J., Acevedo M. 2016. Genome-wide association mapping of leaf rust response in a durum wheat worldwide germplasm collection. The Plant Genome 9 (3): 1-24. DOI: $10.3835 /$ plantgenome2016.01.0008

Behlau F., Scandelai L.H.M., da Silva Junior G.J., Lanza F.E. 2017. Soluble and insoluble copper formulations and metallic copper rate for control of citrus canker on sweet orange trees. Crop Protection 94: 185-191. DOI: 10.1016/j.cropro.2017.01.003

Broers L.H.M., Wallenburg S.C. 1989. Influence of post-infection temperature on three components of partial resistance in wheat to wheat leaf rust. Euphytica 44: 215-224. DOI: 10.1007/BF00037528

Copes W.E., Thomson J.L. 2008. Survival analysis to determine the length of the incubation period of Camellia twig blight caused by Colletotrichum gloeosporioides. Plant Disease 92 (8): 1177-1182. DOI: 10.1094/PDIS-92-8-1177

Drijepondt S.C., Pretorius Z.A. 1989. Greenhouse evaluation of adult-plant resistance conferred by the gene Lr34 to leaf rust of wheat. Plant Disease 73 (8): 669-671. DOI: 10.1094/pd-73-0669

Eversmeyer M., Kramer C., Browder L. 1980. Effect of temperature and host: parasite combination on the latent period of Puccinia recondita in seedling wheat plants. Phytopathology 70 (10): 938-941. DOI : 10.1094/Phyto-70-938 
Eyal Z., Peterson J. 1967. Uredospore production of five races of Puccinia recondita Rob. ex Resm. as affected by light and temperature. Canadian Journal of Botany 45 (4): 537-540. DOI: 10.1139/b67-058

Fisher A.J., Woods A.J., Smith D.M., Bruckart W.L. 2008. Latent period and viability of Puccinia jaceae var. solstitialis urediniospores: Implications for biological control of yellow starthistle. Biological Control 45 (1): 146-153. DOI: 10.1016/j.biocontrol.2007.10.008

Gacek E. 2013. Lista Opisowa Odmian. COBORU, Słupia Wielka, 1174 ss.

Ghini R., Hamada E., Pedro Júnior M.J., Gonçalves R.R.V. 2011. Incubation period of Hemileia vastatrix in coffee plants in Brazil simulated under climate change. Summa Phytopathologica 37 (2): 85-93. DOI: 10.1590/S0100-54052011000200001

Huang Y.J., Liu Z., West J.S., Todd A.D., Hall A.M., Fitt B.D.L. 2007. Effects of temperature and rainfall on date of release of ascospores of Leptosphaeria maculans (phoma stem canker) from winter oilseed rape (Brassica napus) debris in the UK. Annals of Applied Biology 151 (1): 99-111. DOI: 10.1111/j.1744-7348.2007.0015.x

Jeger M.J. 2004. Analysis of disease progress as a basis for evaluating disease management practices. Annual Review of Phytopathology 42: 61-82. DOI: 10.1146/annurev.phyto.42.040803.140427

Johnson D.A. 1980. Effect of low temperature on the latent period of slow and fast rusting winter wheat genotypes. Plant Disease 64: 1006-1008. DOI: 10.1094/PD-64-1006

Karolewski Z., Evans N., Fitt B.D.L., Todd A.D., Baierl A. 2002. Sporulation of Pyrenopeziza brassicae (light leaf spot) on oilseed rape (Brassica napus) leaves inoculated with ascospores or conidia at different temperatures and wetness durations. Plant Pathology 51 (5): 654-665. DOI: 10.1046/j.1365-3059.2002.00746.x

Kleinhenz B., Falke K., Kakau J., Rossberg D. 2007. SIMBLIGHT1 - a new model to predict first occurrence of potato late blight. Bulletin OEPP/EPPO Bulletin 37 (2): 339-343. DOI: 10.1111/j.1365-2338.2007.01135.x

Kluge E., Jörg E., Rossberg D. 2006. SIMSEPT: Eine Entscheidungshilfe zur Bekämpfung von Septoria tritici und Septoria nodorum. [SIMSEPT: A computer aided decision support system for the control of Septoria tritici and Septoria nodorum]. Archives of Phytopathology and Plant Protection 39 (2): 79-92. DOI: 10.1080/03235400500289577

Kolmer J. 2009. Wheat leaf rust. http://www.ars.usda.gov/Main/docs.htm?docid=9915 [dostęp: 12.03.2020].

Kolnaar W. 2006. Influence of rust epidemics on interspecific plant competition. http://ethesis.unifr.ch/theses/downloads.php? file=KolnaarRW.pdf [dostęp: 12.03.2020].

Leclerc M., Doré T., Gilligan C.A., Lucas P., Filipe J.A. 2014. Estimating the delay between host infection and disease (incubation period) and assessing its significance to the epidemiology of plant diseases. PLoS One 9 (1): e86568. DOI: 10.1371/journal.pone.0086568

Lovell D.J., Hunter T., Powers S.J., Parker S.R., Van den Bosch F. 2004. Effect of temperature on latent period of septoria leaf blotch on winter wheat under outdoor conditions. Plant Pathology 53 (2): 170-181. DOI: 10.1111/j.0032-0862.2004.00983.x

Madden L.V., Hughes G., van den Bosch F. 2007. The Study of Plant Disease Epidemics. The APS, St. Paul, MN, USA. ISBN 978-089054-354-2.

Nopsa H.J.F., Pfender W.F. 2014. A latent period duration model for wheat stem rust. Plant Disease 98 (10): 1358-1363. DOI: 10.1094/ PDIS-11-13-1128-RE

Nutter F.F. 2007. The role of plant disease epidemiology in developing successful integrated disease management programs. s. 45-79. W: General Concepts in Integrated Pest and Disease Management. Integrated Management of Plants Pests and Diseases, Vol. 1 (A. Ciancio, K.G. Mukerji, red.). Springer, Dordrecht. ISBN 978-1-4020-6060-1. DOI: 10.1007/978-1-4020-6061-8_3

Pariaud B., Berg F., Bosch F., Powers S.J., Kaltz O., Lannou C. 2013. Shared influence of pathogen and host genetics on a trade-off between latent period and spore production capacity in the wheat pathogen, Puccinia triticina. Evolutionary Applications 6 (2): $303-312$. DOI: $10.1111 /$ eva.12000

Pfender W.F. 2001. A temperature-based model for latentperiod duration in stem rust of perennial ryegrass and tall fescue. Phytopathology 91 (1): 111-116. DOI: 10.1094/PHYTO.2001.91.1.111

Pretorius Z.A., Kloppers F.J., Drijepondt S.C. 1994. Effects of inoculum density and temperature on three components of leaf rust resistance controlled by Lr34 in wheat. Euphytica 74: 91-96. DOI: 10.1007/BF00033772

Racca P., Kleinhenz B., Jörg E. 2007. SIMPEROTA 1/3 - a decision support system for blue mould disease of tobacco. Bulletin OEPP/ EPPO Bulletin 37 (2): 368-373. DOI: 10.1111/j.1365-2338.2007.01139.x

Räder T., Racca P., Jörg E., Hau B. 2007. PUCREC/PUCTRI - a decision support system for the control of leaf rust of winter wheat and winter rye. Bulletin OEPP/EPPO Bulletin 37 (2): 378-382. DOI: 10.1111/j.1365-2338.2007.01140.x

Riaz A., Periyannan S., Aitken E., Hickey L. 2016. A rapid phenotyping method for adult plant resistance to leaf rust in wheat. Plant Methods 12: 17. DOI: 10.1186/s13007-016-0117-7

Savary S., Teng P.S., Willocquet L., Nutter F.W. 2006. Quantification and modeling of crop losses: a review of purposes. Annual Review of Phytopathology 44: 89-112. DOI: 10.1146/annurev.phyto.44.070505.143342

Shakya S.K., Goss E.M., Dufault N.S., van Bruggen A.H.C. 2015. Potential effects of diurnal temperature oscillations on potato late blight with special reference to climate change. Phytopathology 105 (2): 230-238. DOI: 10.1094/PHYTO-05-14-0132-R

Shaner G., Finney R.E. 1980. New sources of slow leaf rusting resistance in wheat. Phytopathology 70: 1183-1186.

Suffert F., Thompson R. 2018. Some reasons why the latent period should not always be considered constant over the course of a plant disease epidemic. Plant Pathology 67 (9): 1831-1840. DOI: 10.1111/ppa.12894

Tomerlin J., Eversmeyer M., Kramer C., Browder L. 1983. Temperature and host effects on latent and infectious periods and on urediniospores of Puccinia recondita f. sp. tritici. Phytopathology 73 (3): 414-419.

van der Gaag D., Jacobs T. 1997. Inheritance of host plant effect on latent period of wheat leaf rust in single-seed descent F8 lines. Euphytica 97: 67-72. DOI: 10.1023/A:1003036905248

van Maanen A., Xu X.-M. 2003. Modelling plant disease epidemics. European Journal of Plant Pathology 109: 669-682. DOI: 10.1023/ A: 1026018005613

Webb C.R., Gilligan C.A., Asher M.J.C. 2000. Modelling the effect of temperature on the development of Polymyxa betae. Plant Pathology 49 (5): 600-607. DOI: 10.1046/j.1365-3059.2000.00483.x

Webb D.H., Nutter F.W. Jr. 1997. Effects of leaf wetness duration and temperature on infection efficiency, latent period, and rate of pustule appearance of rust in alfalfa. Phytopathology 87 (9): 946-950. DOI: 10.1094/PHYTO.1997.87.9.946

Willocquet L., Aubertot J.N., Lebard S., Robert C., Lannou C., Savary S. 2008. Simulating multiple pest damage in varying winter wheat production situations. Field Crops Research 107 (11): 12-28. DOI: 10.1016/j.fcr.2007.12.013 
Windes J.M. 2008. Heating up Idaho agriculture: global warming and its impact on Idaho agriculture. http://www.cals.uidaho.edu/potatoes/Research\&Extension/Conference/2008/Windes.pdf [dostęp: 12.03.2020].

Wójtowicz A. 2012. Opracowanie i walidacja modelu szacującego pojawienie się objawów chorobowych powodowanych przez Puccinia recondita f. sp. tritici. [Validation of a model for estimation appearance of symptoms caused by Puccinia recondita f. sp. tritici]. Progress in Plant Protection 52 (3): 680-683. DOI: 10.14199/ppp-2012-119

Wójtowicz A., Wójtowicz M., Sigvald R., Czernecki B., Ratajkiewicz H., Łacka A., Zacharczuk M., Pasternak M. 2019. Assessment of the impact of climate change on the latency period of leaf rust on triticale in Poland. Acta Agriculturae Scandinavica, Section B - Soil \& Plant Science 70 (3): 195-207. DOI: 10.1080/09064710.2019.1696394

Wójtowicz A., Wójtowicz M., Sigvald R., Pasternak M. 2017. Predicting the effects of climate change on latency period of wheat leaf rust in western Poland. Acta Agriculturae Scandinavica, Section B - Soil \& Plant Science 67 (3): 223-234. DOI: $10.1080 / 09064710.2016 .1248481$

Xu X. 2006. Modelling and interpreting disease progress in time. W: The Epidemiology of Plant Diseases (B. Cooke, D. Jones, B. Kaye, red.). Springer, Dordrecht. ISBN 978-1-4020-4579-0. DOI: 10.1007/1-4020-4581-6 8

$\mathrm{Xu}$ X., Robinson J. 2000. Effects of temperature on the incubation and latent periods of hawthorn powdery mildew (Podosphaera clandestina). Plant Pathology 49 (6): 791-797. DOI: 10.1046/j.1365-3059.2000.00520.x

Xu X.Y., Guihua B., Carver B., Shaner G., Hunger R. 2005. Mapping of QTLs prolonging the latent period of Puccinia triticina infection in wheat. Theoretical and Applied Genetics 110: 244-251. DOI: 10.1007/s00122-004-1819-1 